\title{
Post-depositional loss of nitrate and chloride in Antarctic snow by photolysis and sublimation: a field investigation
}

\author{
Kazushi Noro' ${ }^{10}$ \& Norimichi Takenaka² (1) \\ ${ }^{1}$ Research Institute of Environment, Agriculture and Fisheries, Osaka Prefecture, Habikino, Osaka, Japan; \\ ${ }^{2}$ Graduate School of Humanities and Sustainable System Sciences, Osaka Prefecture University, Sakai, Osaka, Japan
}

\begin{abstract}
Nitrate in snow is subject to post-depositional processing, which leads to a net loss and redistribution within the snowpack. The relative importance of post-depositional loss processes such as the volatilization of nitric acid $\left(\mathrm{HNO}_{3}\right)$ and photolysis of nitrate has long been debated. Changes in nitrate and chloride concentrations in the snowpack were investigated at H128 $\left(69^{\circ} 23.584^{\prime} \mathrm{S}\right.$, $41^{\circ} 33.712^{\prime} \mathrm{E}$ ), an Antarctic coastal site approximately $100 \mathrm{~km}$ from Syowa Station in East Antarctica from December 2015 to February 2016. Results indicate that chloride migrated to deeper sites within the snowpack under the influence of water vapour movement. Moreover, $50 \%$ of the nitrate on surface snow was lost to photolysis, and approximately $20 \%$ of the nitrate was absent at a depth of $40 \mathrm{~cm}$. To enhance our knowledge of the Antarctic geochemical cycle, this study is the first to suggest chloride ion movement in snowpacks or significant nitrate loss for any Antarctic coastal site.
\end{abstract}

To access the supplementary material, please visit the article landing page

\section{Keywords}

Antarctica; geochemical cycle; nitrogen cycle; nitrogen oxides; ozone

\section{Correspondence \\ Kazushi Noro, Research Institute of Environment, Agriculture and Fisheries, Osaka Prefecture, 442, Shakudo, Habikino, Osaka 583-0862, Japan.E-mail: norok@ mbox.kannousuiken-osaka.or.jp \\ Abbreviations \\ a.u.: arbitrary unit \\ JARE57: 57th Japanese Antarctic Research Expedition \\ PTFE: polytetrafluoroethylene \\ SD: standard deviation \\ UV: ultraviolet light}

\section{Introduction}

Nitrate in snow is subject to post-depositional processing, which leads to net loss and redistribution within the snowpack (Röthlisberger et al. 2000; Jacobi \& Hilker 2007; Frey et al. 2009). The relative importance of the volatilization of nitric acid $\left(\mathrm{HNO}_{3}\right)$ and the photolysis of nitrate in the post-depositional loss process have long been debated (Röthlisberger et al. 2000; Blunier et al. 2005). Nitrate photolysis in/on the snowpack is a source of reactive nitrogen oxides $\left(\mathrm{NO}_{y}\right)$ in the atmosphere (Honrath et al. 1999; Jones et al. 2001; Shi et al. 2018). The photochemistry of nitrate in the snowpack has significant implications because its photoproducts- $\mathrm{NO}, \mathrm{NO}_{2}$ and radicals-are intimately linked to reactions involving ozone, hydrocarbons and halogens.

Nitrate undergoes photolysis in the quasi-liquid layer of ice and either $\mathrm{NO}_{2}$ (Eqn. 1) or $\mathrm{NO}_{2}^{-}$(Eqn. 2) is produced (Mack \& Bolton 1999; Grannas et al. 2007; Meusinger et al. 2014).

$$
\mathrm{NO}_{3}^{-}+h v+\mathrm{H}^{+} \rightarrow \mathrm{NO}_{2}+\mathrm{OH}
$$

$$
\mathrm{NO}_{3}^{-}+h v \rightarrow \mathrm{NO}_{2}^{-}+\mathrm{O}\left({ }^{3} \mathrm{P}\right)
$$

Nitrate in ice cores is a potential proxy for historic atmospheric $\mathrm{NO}_{y}$ levels (Dibb et al. 1998). Solar variability on centennial to millennial time scales may imprint on the long-term $\mathrm{NO}_{3}{ }^{-}$record, as suggested by Traversi et al. (2012) in their work on the Talos Dome core record. They reported that traces of solar variability are preserved as nitrate in ice cores drilled in high-accumulation sites (Traversi et al. 2012). However, nitrate concentration in ice cores, which Traversi et al. used as a tracer of solar variability, would have been reduced by the photochemical reactions of nitrate (Noro et al. 2018). Hence, investigation of the nitrate loss in snowpacks at high-accumulation sites is important. In addition, the volatilization of weak acid from the ice surface was reported by Sato et al. (2008). They determined that $\mathrm{HNO}_{3}$ in snow was not volatilized, and hydrochloric acid was volatilized slowly (Sato et al. 2008). It is possible that if snow is investigated for longer than in the study by Sato et al. (2008), $\mathrm{HNO}_{3}$ and more hydrochloric acid may be volatilized. Recently, Shi et al. (2019) reported on their observations of nitrate in an Antarctic snowpack that had undergone isotopic 
fractionation due to the volatilization process. They also reported that the extent of nitrate evaporation was very small at temperatures lower than $-24{ }^{\circ} \mathrm{C}$; however, significant evaporation possibly occurred at $-4^{\circ} \mathrm{C}$ for a few weeks. Therefore, both the photolysis and the evaporation of nitrate have been observed in snowpack extracted from Antarctica.

With the aim of (1) quantifying the chloride and nitrate post-depositional loss in snowpack from Antarctica and (2) determining the snow depth at which nitrate loss occurs, we carried out controlled experiments at an Antarctic coastal site.

\section{Materials and methods}

\section{Location}

Post-depositional process experiments were conducted at H128 $\left(69^{\circ} 23.584^{\prime} \mathrm{S}, 41^{\circ} 33.712^{\prime} \mathrm{E}\right)$, approximately 100 $\mathrm{km}$ from Syowa Station in eastern Dronning Maud Land, East Antarctica, during JARE57, from December 2015 to February 2016.

\section{Nitrate volatilization from the ice surface in the laboratory experiment}

The $\mathrm{pH}$ values of $100 \mathrm{~cm}^{3}$ of the sample solutions, including $100 \mu \mathrm{mol} \mathrm{dm}{ }^{-3}$ of $\mathrm{NaNO}_{3}$, were adjusted using $\mathrm{H}_{2} \mathrm{SO}_{4}$ at a $\mathrm{pH}$ of 2-5 and then placed in Petri dishes with inner diameters of $95 \mathrm{~mm}$ (approximately $1.4 \mathrm{~cm}$ height) for analysis. The dishes were loosely covered with aluminium foil and kept in a freezer at -20 and $-60{ }^{\circ} \mathrm{C}$ for three weeks. Afterwards, the samples were melted at $25{ }^{\circ} \mathrm{C}$ for ion chromatography analysis.

\section{Application of quartation for the mixed snow}

A quartation method was employed for sample homogenization. A polyethylene sheet cleaned with ultra-pure water (resistivity $\geq 18.2 \mathrm{M} \Omega \mathrm{cm}$ ) was placed on a metal frame $\left(90 \times 90 \times 90 \mathrm{~cm}^{3}\right)$ to make a container. The container was then half-filled with surface snow, which was smoothed and divided into four parts. Unmixed blank samples were collected from the centres of the whole sample and the divided parts (a total of five samples). Subsequently, the divided samples were mixed diagonally or orthogonally three times (mixed sample), as shown in Fig. 1. This mixing process is referred to as "quartation" in soil science. The mixed sample was then again divided into four parts to collect mixed blank samples from the centres of the whole sample and the divided parts. The chemical concentrations before and after the homogenization conducted in Antarctica and Japan are shown in Supplementary Table S1.

\section{Natural sample preparation and field sampling}

The sample mixed by the quartation method was packed into Teflon-coated glass tubes with inner diameters of 5 $\mathrm{cm}$ and lengths of $40 \mathrm{~cm}$, as shown in Fig. 2. The glass tubes were then buried in snowpacks under three varying conditions for four weeks. The first condition is the most natural condition: sample tubes were simply buried in a snowpack (OPEN condition). In the second condition, glass beakers were placed on top of the glass tubes to prevent deposition on the sample (COVERED condition), with a gap left to allow air to pass through. Under the third condition, aluminium tape was wrapped around the glass tubes to shield the sunlight, and glass beakers

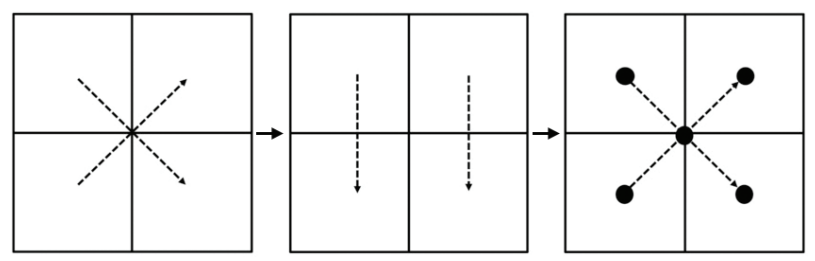

Fig. 1 Quartation mixing step. Black dots show sampling points.

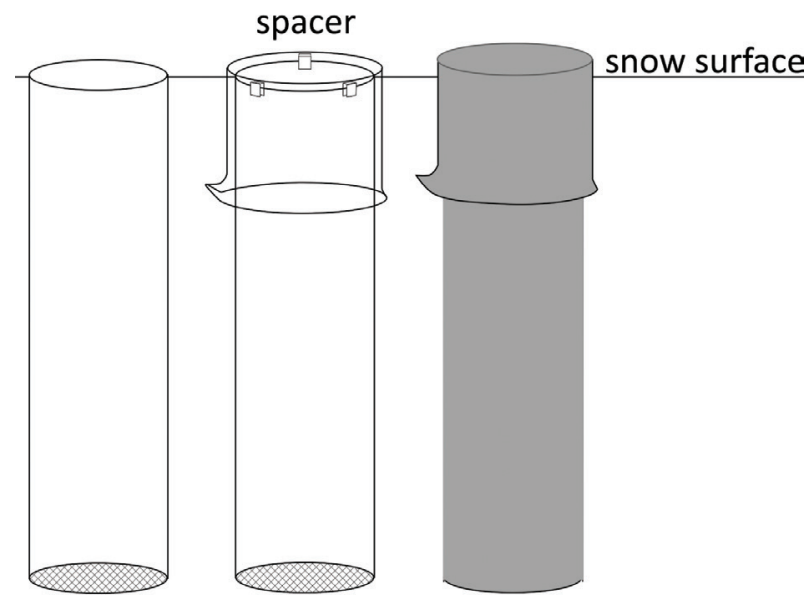

$\begin{array}{lll}\text { (a) OPEN } & \text { (b) COVERED } & \text { (c) DARK }\end{array}$

Fig. 2 The Pyrex glass tubes used for the investigation. The inner walls of the tubes were treated with PTFE. The bottoms were covered with mesh to allow air to pass through and to prevent snow from moving down. (a) In the OPEN experimental condition, the top was open and directly in contact with air. (b) In the COVERED condition, the top was covered with a Pyrex beaker and three PTFE spacers allowed air to pass through and prevented the deposition of new snow and particles. (c) The DARK condition was the same as the COVERED condition, except that the tube and beaker were covered with an aluminium sheet to prevent sunlight irradiation. 
wrapped with aluminium tape were placed on the glass tubes with gaps to allow for airflow (DARK condition). Every week, three glass tubes were collected from each of the three scenarios (OPEN, COVERED and DARK), and the snow cores from the collected tubes were divided into 5-cm sections. Before and after sampling, the samples in the glass tubes were weighed to calculate the sample density (ca. $0.50 \mathrm{~g} \mathrm{~cm}^{-3}$ ). The cut samples were stored in clean bags in a frozen state prior to laboratory analysis in Japan.

\section{Amended sample preparation and field sampling}

The containers were set up, and natural snow samples were prepared. Thereafter, $100 \mathrm{~cm}^{3}$ of $\mathrm{NaCl}, \mathrm{NH}_{4} \mathrm{Cl}$ and $\mathrm{NaNO}_{3}$ (100 mmol dm ${ }^{-3}$ each) solution was sprayed onto the snow sample. Subsequent mixing, glass tube packing and sampling procedures were conducted as for the natural snow sample (amended sample).

\section{Observation of sunlight intensity in the snowpack}

Light intensity in the snowpack was observed with a $1.3 \mathrm{~m}$ depth pit. An optical fibre spectrophotometer system with a UV/Vis probe (Ocean Optics TP300-UV/VIS probe and USB2000+UV-VIS-ES) was used for the observation. The tip of the probe in a right-angle prism was inserted up to approximately $90 \mathrm{~cm}$ from the side of the pit wall at depths of 10, 20, 30, 50, 75 and $100 \mathrm{~cm}$ (Fig. 3 ). The probe was rotated to $0^{\circ}$ (upward in vertical direction), $45^{\circ}, 90^{\circ}$ (side), $135^{\circ}$ and $180^{\circ}$ (downward in vertical direction) to measure the light intensity in the snow pit from these selected directions. In addition, the reference was measured by placing the probe, which was set to $30 \mathrm{~cm}$ above the reflector (SRT-99-050, Labsphere), at a fixed height of $150 \mathrm{~cm}$.

We calculated the e-folding depth of actinic flux in the snowpack according to the Beer-Bouguer-Lambert
Law (Eqn. 3; France et al. 2011). The e-folding depth was defined as the depth where the actinic flux would be 1/e times (ca. 37\%; France et al. 2011).

$$
I_{z}=I_{z^{\prime}} \times \exp \left(\varepsilon^{-1} \times\left(z-z^{\prime}\right)\right)
$$

where $z(\mathrm{~cm})$ is the depth, $z^{\prime}(\mathrm{cm})$ is the initial depth $(z>$ $\left.z^{\prime}\right), I_{z}$ is the light intensity (a.u.) at depth $z, I_{z^{\prime}}$ (a.u.) is the light intensity at depth $z^{\prime}$ and $\varepsilon(\mathrm{cm})$ is the e-folding depth. The average of solar intensities at $90^{\circ}$ and $270^{\circ}$ was used to calculate $\varepsilon$, in the same manner as in previous reports (France et al. 2011). Additionally, the solar intensity in the snowpack was normalized by the sunlight intensity measured by an automatic weather station.

\section{Temperature observation of the snow}

To determine the temperature of the snow samples, type-k thermocouples were connected to a portable temperature and humidity data logger (TR-72Ui-type Thermo Recorder, T\&D Corporation). The thermocouples were inserted into the snowpack at 0, 10, 20, 30 and $40 \mathrm{~cm}$ depths to measure the temperature gradient in the snowpack continuously (Fig. 4). After setting the thermocouples, the snow was returned to the pit and the temperature at each depth was measured continuously.

\section{Ion chromatography analysis}

Ion concentrations in the samples were analysed by ion chromatography in the laboratory. Amended samples were diluted 20 times with ultra-pure water. The anion chromatograph system (883 basic IC plus, Metrohm) consisted of a guard column (SI-90G, Shodex), separation column (SI-90 4E, Shodex) and suppressor for anion analysis, and the eluent was a mixed solution of $1.8 \mathrm{mmol} \mathrm{dm}^{-3} \mathrm{Na}_{2} \mathrm{CO}_{3}$ and $1.7 \mathrm{mmol} \mathrm{dm}^{-3}$ $\mathrm{NaHCO}_{3}$, with a flow rate at $1 \mathrm{~cm}^{3} \mathrm{~min}^{-1}$. The cation
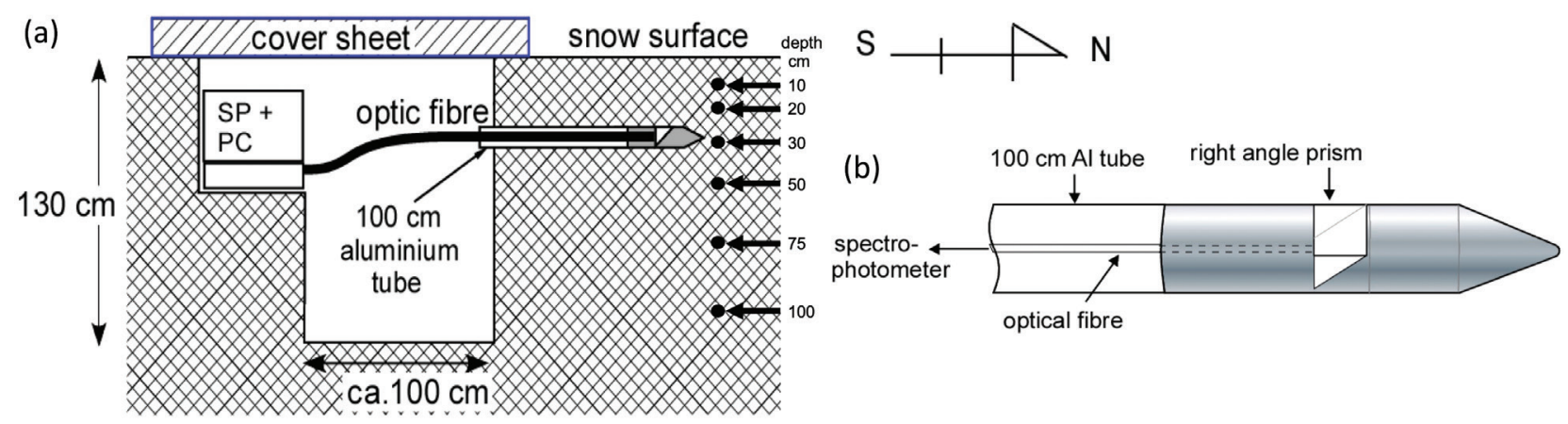

Fig. 3 Schematic diagram of how light intensity was observed in the snowpack: (a) overall picture; (b) enlarged illustration of the light-receiving unit. 


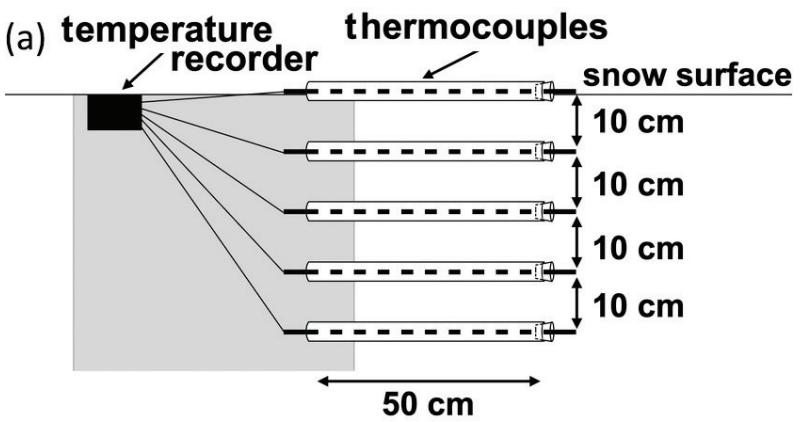

(b)

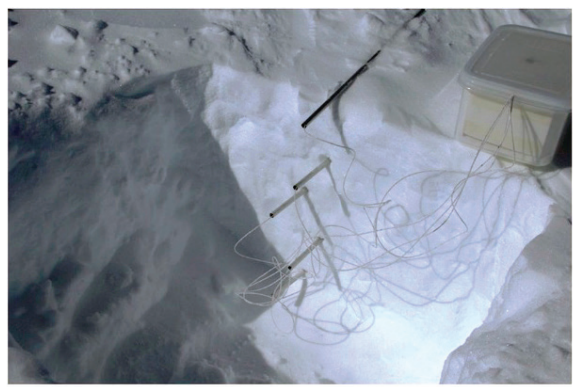

Fig. 4 Temperature observations in the snowpack: (a) schematic diagram of temperature instrument; (b) photograph of the temperature instrument. Snow in the grey area of (a) was removed and then backfilled after the thermocouples were set.

chromatograph system (IC7000, Yokogawa) consisted of a separation column (YS-50, Shodex) and an eluent made up of $4 \mathrm{mmol} \mathrm{dm} \mathrm{dm}^{-3}$ methanesulfonic acid at $1 \mathrm{~cm}^{3}$ $\min ^{-1}$ flow rate.

\section{Results}

\section{Nitrate volatilization from the ice surface}

Figure 5 shows the decrease in the nitrate concentration from the ice surface during the three-week study period at temperatures of -20 and $-60{ }^{\circ} \mathrm{C}$. Because the apparent ion concentration changes with the evaporation of water, nitrate concentrations were standardized by $\left[\mathrm{Na}^{+}\right]$. At $-60{ }^{\circ} \mathrm{C}$, the nitrate concentration decreased by approximately $3 \mu \mathrm{mol} \mathrm{dm}{ }^{-3}$ at a $\mathrm{pH}$ of between 2 and 5 . At -60 ${ }^{\circ} \mathrm{C}$, there is no liquid phase on the ice; therefore, nitrate ions cannot bond to protons, restricting nitrate volatilization. Therefore, we did not observe a pH dependence of nitrogen volatilization in our experiments at $-60{ }^{\circ} \mathrm{C}$. At $-20{ }^{\circ} \mathrm{C}$, nitrate volatilization showed a peak at a $\mathrm{pH}$ of 3 . The volatilization of hydrochloric acid has already been reported (Sato et al. 2008) and tends to proceed at lower $\mathrm{pH}$ levels. Due to the effects of the freezing concentration effect, the volatilization of acid from the ice surface occurred by combining the concentrated $\mathrm{H}^{+}$ions
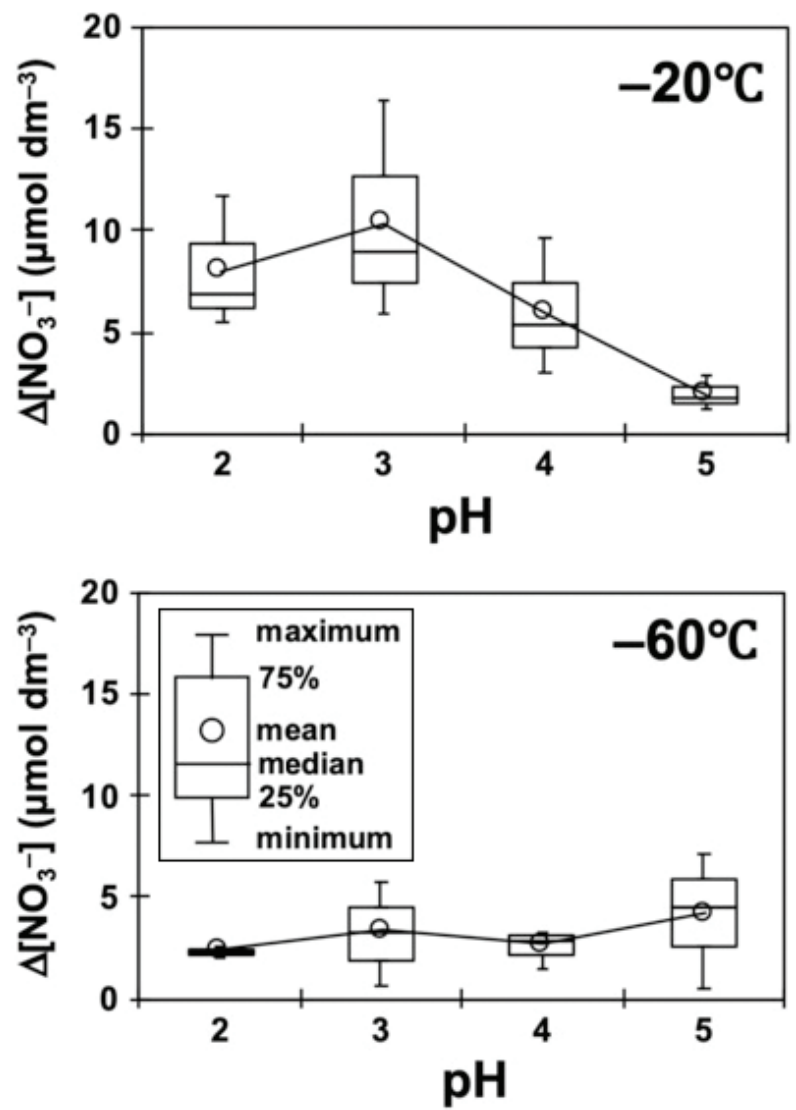

Fig. 5 Decreased amounts of nitrate standardized with [ $\left.\mathrm{Na}^{+}\right]$by volatilization from the ice surface for the three-week period, at temperatures of -20 and $-60{ }^{\circ} \mathrm{C}$. Initial $\mathrm{NaNO}_{3}$ concentration was $100 \mu \mathrm{mol} \mathrm{dm}{ }^{-3} ; \mathrm{pH}$ was adjusted with $\mathrm{H}_{2} \mathrm{SO}_{4}$. There were three samples.

with the counter anions. However, at a pH of 2, the high concentration of sulfuric acid $(5 \mathrm{mM})$ inhibited the freeze concentration effect, decreasing nitrate volatilization. This suggests that the volatilization of nitrate as a post-depositional process may occur in environments like Antarctica where nitrate is present on the ice surface for long periods.

\section{Homogenization of snow sample by quartation}

Supplementary Table Sl shows the ion concentrations and relative SDs of the unmixed and mixed snow samples. Except for the chloride concentration of one sample collected at H128, variations in all the samples reduced after quartation. The unchanged chloride concentration in the H128 sample may be due to limitations in the accuracy of the ion chromatograph rather than ineffectiveness of the quartation process, which produced good results for snow equalization. 


\section{Temperature in the snowpack}

Supplementary Fig. Sla shows the temperature change in the snowpack at the depths of $0,10,20,30$ and $40 \mathrm{~cm}$, as well as the atmospheric temperature measured by an automatic weather station on 2-22 January 2016. Supplementary Fig. S1b shows the atmospheric temperatures recorded on 4 January 2016. The surface temperature fluctuated significantly between 3.9 and $-22.8{ }^{\circ} \mathrm{C}$ on the account of sunlight heating and radiative cooling. Note that temperatures above $0{ }^{\circ} \mathrm{C}$ were caused by the direct solar heating of the sensor; snowmelt was not observed during these experiments. The maximum and minimum daily temperatures were observed at approximately 13:30 and 01:30, respectively. Deeper in the snowpack, the amplitude of the temperature variations decreased. In addition, owing to the adiabatic effect of snow, the time of the temperature peaks at the deeper sites gradually lagged behind that of the surface temperature peaks. The width shift and lag of temperature peaks should change the thermal gradient in the snowpack, controlling the direction of the water vapour movement in a complex manner.

\section{Change in concentrations of ions in natural snow in Antarctica}

Concentrations of $\mathrm{Na}^{+}, \mathrm{Cl}^{-}, \mathrm{NO}_{3}^{-}$and $\mathrm{SO}_{4}{ }^{2-}$ in the unmixed blank samples were $8.4 \pm 4.3,5.9 \pm 0.2$,
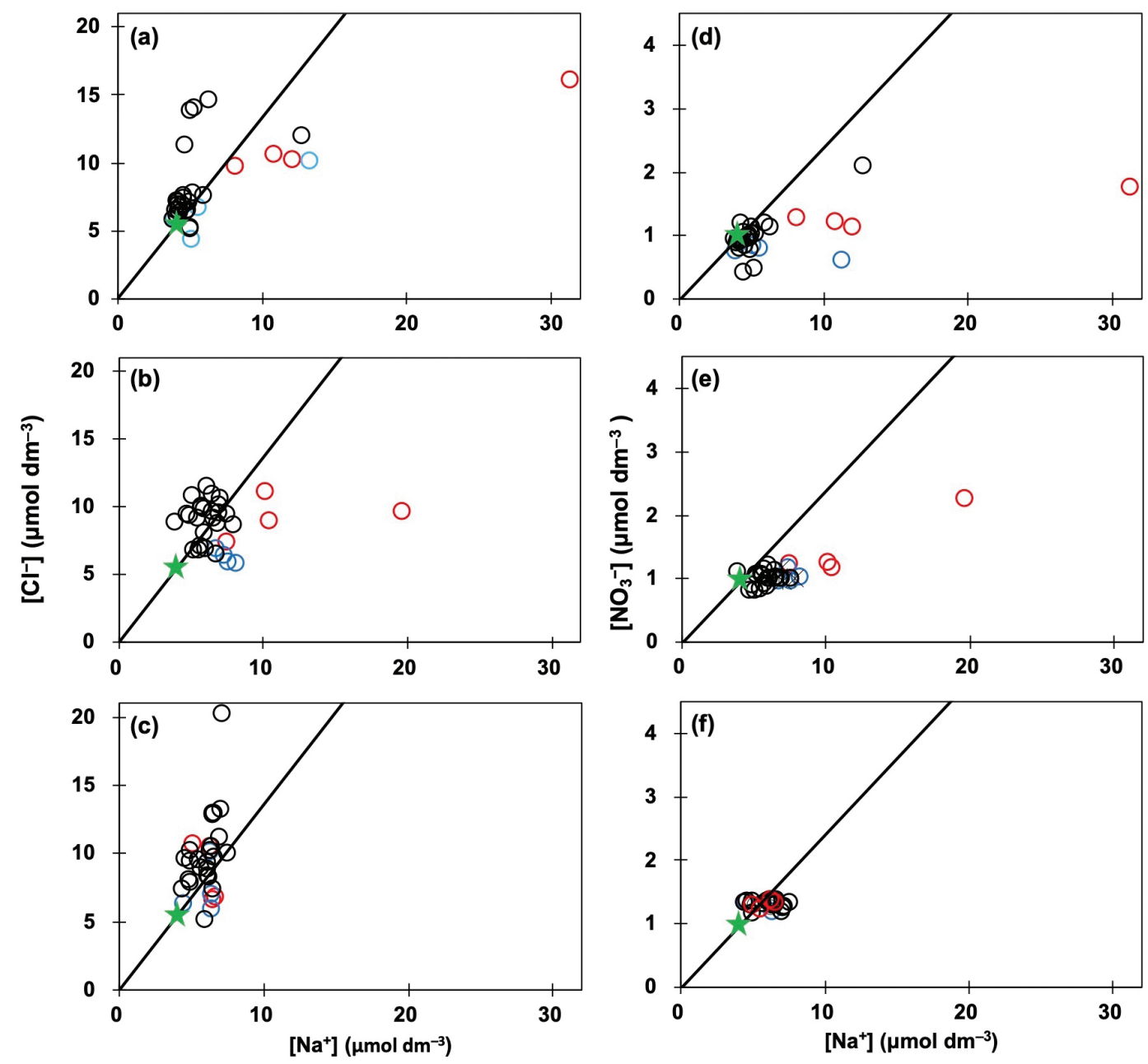

○ 0-5 cm depth $\bigcirc 5-10 \mathrm{~cm}$ depth $\bigcirc 10-20,20-30$ and $30-40 \mathrm{~cm}$ depth $\star$ mixed blank sample

Fig. $6[\mathrm{Cl}-]$ versus $\left[\mathrm{Na}^{+}\right]$and $\left[\mathrm{NO}_{3}{ }^{-}\right]$versus $\left[\mathrm{Na}^{+}\right]$in the natural samples. The slope of the line is the $\left[\mathrm{Cl}^{-}\right] /\left[\mathrm{Na}^{+}\right]$and $\left[\mathrm{NO}_{3}{ }^{-}\right] /\left[\mathrm{Na}^{+}\right]$of the mixed blank sample. (a) OPEN; (b) COVERED; and (c) DARK for [Cl-] versus [Na+]. (d) OPEN; (e) COVERED; and (f) DARK for [ $\left.\mathrm{NO}_{3}{ }^{-}\right]$versus [ $\left.\mathrm{Na}^{+}\right]$. 
$1.7 \pm 0.5$ and $2.0 \pm 0.6 \mu \mathrm{mol} \mathrm{dm}^{-3}$, respectively $(n=$ 5 , error $=1 \mathrm{SD})$, while those in mixed blank samples were $4.2 \pm 0.9,5.6 \pm 0.3,1.0 \pm 0.1$ and $1.3 \pm 0.04 \mu \mathrm{mol}$ $\mathrm{dm}^{-3}$, respectively $(n=5$, error $=1 \mathrm{SD}$; Supplementary Table S1). Figure 6 shows the results of these samples. As the apparent ion concentrations change with the evaporation of water, we could not determine whether changes observed in the ion concentrations of the natural samples were due to water vapour movement or increases and decreases in the absolute concentrations of the ions. Therefore, the concentrations of $\mathrm{Cl}^{-}$and $\mathrm{NO}_{3}^{-}$ were compared with that of $\mathrm{Na}^{+}$, for which the absolute amount did not change. Note that dry deposition of $\mathrm{Na}^{+}$ could increase the $\mathrm{Na}^{+}$concentration instead of water evaporation. However, the $\mathrm{Na}^{+}$concentration increment was observed under both OPEN and COVERED conditions. We therefore concluded that the reason of the $\mathrm{Na}^{+}$concentration change was the water evaporation. The stars in Fig. 6 show the $\left[\mathrm{Cl}^{-}\right] /\left[\mathrm{Na}^{+}\right]$and $\left[\mathrm{NO}_{3}{ }^{-}\right] /$ $\left[\mathrm{Na}^{+}\right]$of the mixed blank sample. If the ion concentration change was due to water vapour movement only, all the plots would be on the straight lines, as shown in the figures. Additionally, if a plot occurs on the right side of this line, it indicates that the concentration of $\mathrm{Cl}^{-}$ or $\mathrm{NO}_{3}{ }^{-}$decreased after the post-depositional processes occurred. Conversely, if the plot is on the left side of this line, the concentration of $\mathrm{Cl}^{-}$or $\mathrm{NO}_{3}{ }^{-}$increased after the occurrence of post-depositional processes or because of deposition from the atmosphere. Under the conditions of OPEN and COVERED, $\mathrm{Cl}^{-}$was lost in the surface snow (0-5 and 5-10 cm depth). We observed a significant difference between the $\left[\mathrm{Cl}^{-}\right] /\left[\mathrm{Na}^{+}\right]$of the surface snow sample (0-5 and 5-10 cm depth; $p=0.05)$. However, the $\left[\mathrm{Cl}^{-}\right] /\left[\mathrm{Na}^{+}\right]$under the DARK condition was stable. Similar to the $\mathrm{Cl}^{-}$results, $\mathrm{NO}_{3}{ }^{-}$was lost in the surface snow (0-5 and 5-10 cm depth) under the OPEN and COVERED conditions. There was also a significant difference between the $\left[\mathrm{NO}_{3}{ }^{-}\right] /\left[\mathrm{Na}^{+}\right]$of the surface snow sample $(0-5$ and $5-10 \mathrm{~cm}$ depth; $p=0.05)$. Because most of the data plotted on the right side of the blank under all three conditions, we can conclude that water evaporation occurred in the glass tube. As a result of this water vapour movement, the surface snow became drier, which may have led to the volatilization of $\mathrm{HCl}$ and other organic acids. Even under the DARK condition, water vapour movement dried the sample, and the data plotted on the blank line. In other words, $\mathrm{HCl}$ emission into the atmosphere does not progress under DARK conditions. A possible reason for this observation is the lower water evaporation in the DARK condition than in the OPEN and COVERED conditions (Fig. 6). Compared to the OPEN and COVERED conditions, the $\left[\mathrm{Na}^{+}\right]$at $0-5$ $\mathrm{cm}$ depth was relatively low, which could be attributed to lower water evaporation. The concentration gradient under the DARK condition would therefore be leaner than in other conditions. While nitrate ions behave similarly to chloride ions, the reasons for their behaviour are different, as discussed later. The main cause of nitrate ion loss would be photolysis. Because the photolysis reaction could not proceed, nitrate concentrations were stable under the DARK condition. Under the OPEN and COVERED conditions, data collected at sample depths greater than $10 \mathrm{~cm}$ plotted on the right side of the line. This indicates that nitrate photolysis may proceed even deeper than $10 \mathrm{~cm}$ in the snowpack. Moreover, under the OPEN and COVERED conditions, the glass tubes prevent the penetration of UV from the side, suggesting that more nitrate can be photolysed in natural conditions than shown in the experiment. Although nitrate photolysis may produce $\mathrm{NO}_{2}^{-}$, this ion was not detected. Therefore, all the $\mathrm{NO}_{y}$ generated by nitrate photolysis are released into the atmosphere as gases.

The $\mathrm{Cl}^{-}$and $\mathrm{NO}_{3}^{-}$behaviour in the mixed amended samples was similar to that of the natural samples (Supplementary Fig. S2). This implies that an amended sample could be suitable to conduct an experiment to estimate the post-depositional process in a laboratory when natural Antarctic snow is unavailable. Note that the $\mathrm{Cl}^{-}$values of the amended samples in the lower layers are on the straight lines, which means that the $\mathrm{Cl}^{-}$concentration changes were due to the water evaporation effect. $\mathrm{Cl}^{-}$did not volatilize in this condition, presumably because there

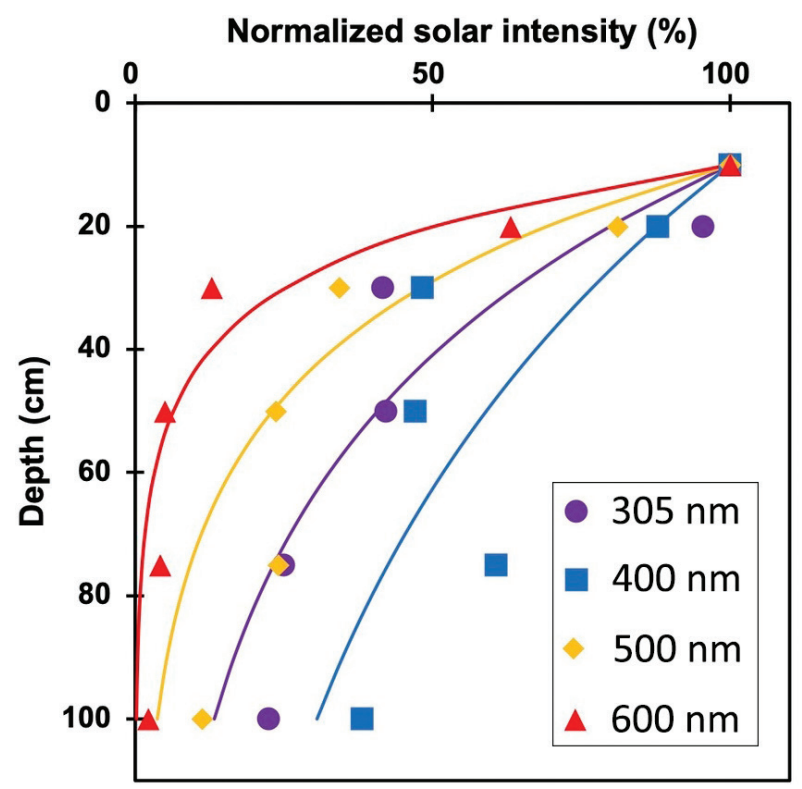

Fig. 7 Depth profile of normalized light intensity, measured at 12:0016:00 on 14 January 2015. 
was insufficient $\mathrm{H}^{+}$required for bonding with the $\mathrm{Cl}^{-}$to volatilize as $\mathrm{HCl}$ gas. An excessive amount of $\mathrm{Cl}^{-}$had been added to the amended sample.

\section{Discussion \\ e-folding depth}

The normalized solar intensities and depth dependence of the solar spectrum are shown in Fig. 7 and Supplementary Fig. S3. Several studies have reported the e-folding depth at $305 \mathrm{~nm}$ in Antarctica as 2-5, $8-12,15-31,10-21$ and 24-69 cm, which are dependent on the snow impurity (France et al. 2011; Zatko et al. 2013; Zatko et al. 2016; Winton et al. 2020). Our result for $\varepsilon(45 \mathrm{~cm})$ was within a range of the $\varepsilon$ (24-69 cm) calculated by a model (Zatko et al. 2016; Fig. 7). However, our result was relatively deeper than that of the field observations of 2-5, 8-12, 15-31 and 10-20 cm (France et al. 2011; Zatko et al. 2013; Winton et al. 2020). A shallower $\varepsilon(8-12 \mathrm{~cm})$ and deeper $\varepsilon(15-31 \mathrm{~cm})$ were observed near a station and about $11 \mathrm{~km}$ away, respectively, and these differences were attributed to the greater snow impurity near the station, as a result of human activities there (Zatko et al. $2013)$. This suggests that the relatively deeper $\varepsilon(45 \mathrm{~cm})$ observed in this study would be due to the lower snow impurity more than $100 \mathrm{~km}$ away from Syowa Station.

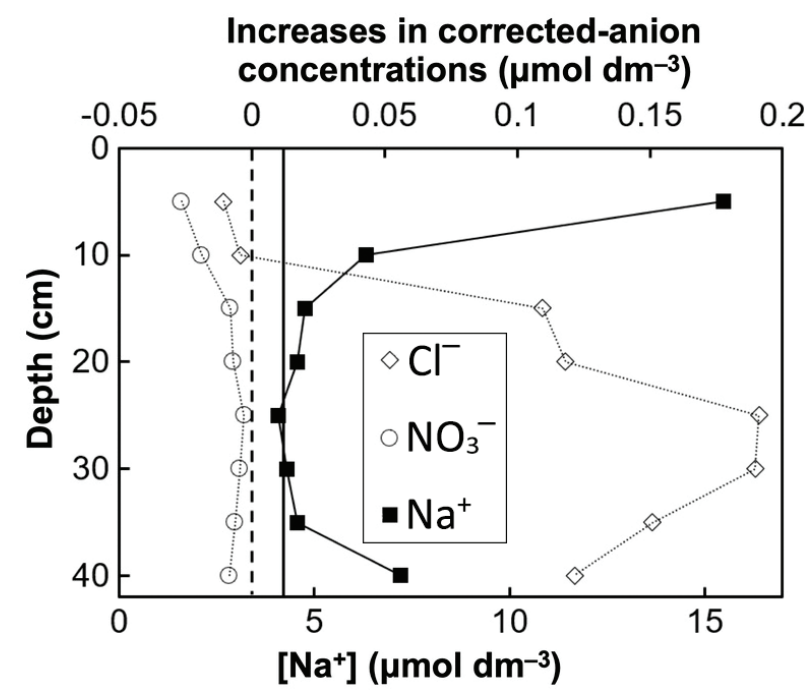

Fig. 8 Depth profile of $\mathrm{Cl}^{-}$and $\mathrm{NO}_{3}{ }^{-}$losses and $\left[\mathrm{Na}^{+}\right]$after 28 days for the OPEN samples. Solid and dashed lines indicate the initial concentration of [ $\left.\mathrm{Na}^{+}\right]$(lower axis) and zero values for the increased corrected anion concentrations (upper axis), respectively.

\section{Estimation of the post-depositional loss of chloride and nitrate}

The density of snow in the glass tube was approximately $0.5 \mathrm{~g} \mathrm{~cm}^{-3}$ and, from this, chloride and nitrate losses at each depth were calculated. Figure 8 shows the changes in the chloride, nitrate and sodium concentrations under OPEN conditions after four weeks. The $\left[\mathrm{Na}^{+}\right]$at a depth of $2.5 \mathrm{~cm}$ was relatively high, and the water at this depth evaporated. This shows that first-order reactions (i.e., volatilization and photolysis) are affected by changes in concentration of chloride and nitrate caused by the water evaporation. The change in the $\left[\mathrm{Cl}^{-}\right]$was small at this depth; however, the concentration increased with increasing depth: $\mathrm{HCl}$ deposited on the surface of the snowpack gradually migrated downwards. $\mathrm{Cl}^{-}$initially moved through the snowpack as $\mathrm{HCl}$ gas or in the grain boundary of the ice as $\mathrm{Cl}^{-}$. The reason for the migration was the concentration gradient from the higher $\left[\mathrm{Cl}^{-}\right]$at the surface to the lower $\left[\mathrm{Cl}^{-}\right]$deeper down, caused by water evaporation. Additionally, convection within the snowpack would influence the migration. Either way, all the $\mathrm{Cl}^{-}$deposited on the surface migrated through the snowpack, which suggests that other chemical species may also move in the snowpack.

Nitrate near the surface decreased by more than $50 \%$. Previous investigations have suggested that the degree of post-depositional nitrate loss depends largely on the rate of snow accumulation, and photolytic nitrate loss occurs significantly at low snow accumulation sites (Erbland et al. 2013; Erbland et al. 2015; Zatko et al. 2016; Noro et al. 2018; Shi et al. 2018; Winton et al. 2020). Since the surface snow is buried after a short time at highaccumulation sites, the nitrate loss by photolysis should be nominal there. However, Savarino et al. (2007) observed that the increase in the particulate nitrate concentration in the atmosphere at a coastal site was a result of the re-emission of $\mathrm{NO}_{y}$ species from snow. Snow precipitation was not observed during the present investigation at the site (H128), which was a high-accumulation site, which implies that the nitrate remained on the snow surface during the experiments (Noro et al. 2018). In other words, nitrate photolysis can occur under a low-accumulation condition at coastal sites where post-depositional loss of nitrate was not believed to have occurred (Erbland et al. 2013; Noro et al. 2018; Shi et al. 2018). Moreover, the loss of chloride in the snow, which has a higher volatilization rate than nitrate, was not observed in the glass tube experiments. Therefore, photolysis dominated the post-depositional process of nitrate in the present study, and volatilization proceeded as a minor process.

Nearly $20 \%$ of the nitrate disappears completely, even at a depth of $40 \mathrm{~cm}$. This observation can be explained by 
light of $305 \mathrm{~nm}$ penetrating deeper sites in the snowpack, as previously mentioned. Most of the nitrate remained at $25 \mathrm{~cm}$ because the glass wall obstructed the light at this depth. The nitrate loss was therefore underestimated. In the lower part of the glass tube, photolysis was enabled using light penetrating from the shallower sites.

\section{Conclusion}

Our study reveals new and significant information about the Antarctic geochemical cycle. We found that chloride migrated down into the snowpack due to the influence of water vapour movement. Moreover, $50 \%$ of the nitrate on surface snow was lost to photolysis, and approximately $20 \%$ of the nitrate was absent at a depth of $40 \mathrm{~cm}$. This is the first report of chloride ion movement and a notable nitrate loss at any Antarctic coastal site. Our results show that the post-depositional process should be taken into account when interpreting nitrate records from coastal sites, as the amount of nitrate may be underestimated if this process is not considered at high-accumulation sites.

\section{Acknowledgements}

The authors thank the members of JARE57 for their fieldwork assistance during the expedition from December 2015 to February 2016. The authors also thank Miho Arai, Toshimitsu Sakurai, Kenji Kawamura and Hideaki Motoyama for their technical assistance during the field observations in Antarctica.

\section{Disclosure statement}

The authors report no conflict of interest.

\section{Funding}

The work was partially supported by the System-inspired Leaders in Material Science (SiMS) Program of Osaka Prefecture University, Japan and the Japan Society for the Promotion of Science (JSPS) KAKENHI Grant Number JP24651015.

\section{References}

Blunier T., Floch G.L., Jacobi H.-W. \& Quansah E. 2005. Isotopic view on nitrate loss in Antarctic surface snow. Geophysical Research Letters 32, L13501, doi: 10.1029/2005GL023011.

Dibb J.E., Talbot R.W., Munger J.W., Jacob, D.J. \& Fan S.-M. 1998. Air-snow exchange of HNO3 and $\mathrm{NO}_{y}$ at Summit,
Greenland. Journal of Geophysical Research-Atmospheres 103, 3475-3486, doi: 10.1029/97JD03132.

Erbland J., Savarino J., Morin S., France J.L., Frey M.M. \& King M.D. 2015. Air-snow transfer of nitrate on the East Antarctic Plateau-part 2: an isotopic model for the interpretation of deep ice-core records. Atmospheric Chemistry and Physics 15, 12079-12113, doi: 10.5194/acpd-15-6887-2015.

Erbland J., Vicars W.C., Savarino J., Morin S., Frey M.M., Frosini D., Vince E. \& Martins J.M.F. 2013. Air-snow transfer of nitrate on the East Antarctic Plateau-part 1: isotopic evidence for a photolytically driven dynamic equilibrium in summer. Atmospheric Chemistry and Physics 13, 6403-6419, doi: 10.5194/acp-13-6403-2013.

France J.L., King M.D., Frey M.M., Erbland J., Picard G., Preunkert S., MacArthur A. \& Savarino J. 2011. Snow optical properties at Dome C (Concordia), Antarctica; implications for snow emissions and snow chemistry of reactive nitrogen. Atmospheric Chemistry and Physics 11, 9787-9801, doi: 10.5194/acp-11-9787-2011.

Frey M.M., Savarino J., Morin S., Erbland J. \& Martins J.M.F. 2009. Photolysis imprint in the nitrate stable isotope signal in snow and atmosphere of East Antarctica and implications for reactive nitrogen cycling. Atmospheric Chemistry and Physics 9, 8681-8696, doi: 10.5194/ acp-9-8681-2009.

Grannas A.M., Jones A.E., Dibb J., Ammann M., Anastasio C., Beine H.J., Bergin M., Bottenheim J., Boxe C.S., Carver G., Chen G., Crawford J.H., Dominé F., Frey M.M., Guzmán M.I., Heard D.E., Helmig D., Hoffmann M.R., Honrath R.E., Huey L.G., Hutterli M., Jacobi H.W., Klán P., Lefer B., McConnell J., Plane J., Sander R., Savarino J., Shepson P.B., Simpson W.R., Sodeau J.R., von Glasow R., Weller R., Wolff E.W. \& Zhu T. 2007. An overview of snow photochemistry: evidence, mechanisms and impacts. Atmospheric Chemistry and Physics 7, 4329-4373, doi: 10.5194/acp-7-4329-2007.

Honrath R.E., Peterson M.C., Guo S., Dibb J.E., Shepson P.B. $\&$ Campbell B. 1999. Evidence of $\mathrm{NO}_{x}$ production within or upon ice particles in the Greenland snowpack, Geophysical Research Letters 26, 695-698, doi: 10.1029/1999GL900077.

Jacobi H.-W. \& Hilker B. 2007. A mechanism for the photochemical transformation of nitrate in snow. Journal of Photochemistry and Photobiology A: Chemistry 185, 371-382, doi: 10.1016/j.jphotochem.2006.06.039.

Jones A.E., Weller R., Anderson P.S., Jacobi H.W., Wolff E.W., Schrems O. \& Miller H. 2001. Measurements of $\mathrm{NO}_{x}$ emissions from the Antarctic snowpack. Geophysical Research Letters 28, 1499-1502, doi: 10.1029/2000GL01 1956.

Mack J. \& Bolton J.R. 1999. Photochemistry of nitrite and nitrate in aqueous solution: a review. Journal of Photochemistry and Photobiology A: Chemistry 128, 1-13, doi: 10.1016/ S1010-6030(99)00155-0.

Meusinger C., Berhanu T.A., Erbland J., Savarino J. \& Johnson M.S. 2014. Laboratory study of nitrate photolysis in Antarctic snow. I. Observed quantum yield, domain of photolysis, and secondary chemistry. The Journal of Chemical Physics 140, 244305, doi: 10.1063/1.4882898.

Noro K., Hattori S., Uemura R., Fukui K., Hirabayashi M., Kawamura K., Motoyama H., Takenaka N. \& Yoshida N. 
2018. Spatial variation of isotopic compositions of snowpack nitrate related to post-depositional processes in eastern Dronning Maud Land, East Antarctica. Geochemical Journal 52, e7-e14, doi: 10.2343/geochemj.2.0519.

Röthlisberger R., Hutterli M.A., Sommer S., Wolff E.W. \& Mulvaney R. 2000. Factors controlling nitrate in ice cores: evidence from the Dome C deep ice core. Journal of Geophysical Research-Atmospheres 105, 20565-20572, doi: 10.1029/2000JD900264.

Sato K., Takenaka N., Bandow H. \& Maeda Y. 2008. Evaporation loss of dissolved volatile substances from ice surfaces. The Journal of Physical Chemistry A 112, 7600-7607, doi: 10.1021/jp075551r.

Savarino J., Kaiser J., Morin S., Sigman D.M. \& Thiemens M.H. 2007. Nitrogen and oxygen isotopic constraints on the origin of atmospheric nitrate in coastal Antarctica. Atmospheric Chemistry and Physics 7, 1925-1945, doi: 10.5194/acp-7-1925-2007.

Shi G., Buffen A.M., Ma H., Hu Z., Sun B., Li C., Yu J., Ma T., An C., Jiang S., Li Y. \& Hastings M.G. 2018. Distinguishing summertime atmospheric production of nitrate across the East Antarctic Ice Sheet. Geochimica et Cosmochimica Acta 231, 1-14, doi: 10.1016/j.gca.2018.03.025.

Shi G., Chai J., Zhu Z., Hu Z., Chen Z., Yu J., Ma T., Ma H., An C., Jiang S., Tang X. \& Hastings M.G. 2019. Isotope fractionation of nitrate during volatilization in snow: a field investigation in Antarctica. Geophysical Research Letters 46, 3287-3297, doi: 10.1029/2019GL081968.

Traversi R., Usoskin I.G., Solanki S.K., Becagli S., Frezzotti M., Severi M., Stenni B. \& Udisti R. 2012. Nitrate in polar ice: a new tracer of solar variability. Solar Physics 280, 237-254, doi: 10.1007/s1 1207-012-0060-3.

Winton V.H.L., Ming A., Caillon N., Hauge L., Jones A.E., Savarino J., Yang X. \& Frey M.M. 2020. Deposition, recycling, and archival of nitrate stable isotopes between the air-snow interface: comparison between Dronning Maud Land and Dome C, Antarctica. Atmospheric Chemistry and Physics 20, 5861-5885, doi: 10.5194/acp-20-5861-2020.

Zatko M.C., Geng L., Alexander B., Sofen E. \& Klein K. 2016. The impact of snow nitrate photolysis on boundary layer chemistry and the recycling and redistribution of reactive nitrogen across Antarctica and Greenland in a global chemical transport model, Atmospheric Chemistry and Physics 16, 2819-2842, doi: 10.5194/acp-16-2819-2016.

Zatko M.C., Grenfell T.C., Alexander B., Doherty S.J., Thomas J.L. \& Yang X. 2013. The influence of snow grain size and impurities on the vertical profiles of actinic flux and associated $\mathrm{NO}_{x}$ emissions on the Antarctic and Greenland ice sheets. Atmospheric Chemistry and Physics 13, 3547-3567, doi: 10.5194/acp-13-3547-2013. 